\title{
Sex ratio in two species of Pegoscapus wasps (Hymenoptera: Agaonidae) that develop in figs: can wasps do mathematics, or play sex ratio games?
}

\author{
William Ramírez-Benavides 1 , Julián Monge-Nájera 2 \& Juan B. Chavarría 3 \\ 1. Facultad de Ciencias Agroalimentarias, Universidad de Costa Rica, 2060 San José, Costa Rica; clizano@yahoo.com \\ 2. Revista Biología Tropical, Universidad de Costa Rica, 2060 San José, Costa Rica; julianmonge@gmail.com \\ 3. Escuela de Estadística, Universidad de Costa Rica, 2060 San José, Costa Rica; jchavarr@cariari.ucr.ac.cr
}

Received 29-X-2007. C Corrected 22-II-2009. Accepted 25-III-2009.

\begin{abstract}
The fig pollinating wasps (Hymenoptera: Agaonidae) have obligate arrhenotoky and a breeding structure that fits local mate competition (LMC). It has been traditionally assumed that LMC organisms adjust the sex ratio by laying a greater proportion of male eggs when there is superparasitism (several foundresses in a host). We tested the assumption with two wasp species, Pegoscapus silvestrii, pollinator of Ficus pertusa and Pegoscapus tonduzi, pollinator of Ficus eximia $(=F$. citrifolia), in the Central Valley of Costa Rica. Total number of wasps and seeds were recorded in individual isolated naturally colonized syconia. There was a constant additive effect between the number of foundresses and the number of males produced in the brood of a syconium, while the number of females decreased. Both wasp species seem to have precise sex ratios and probably lay the male eggs first in the sequence, independently of superparasitism and clutch size: consequently, they have a non-random sex allocation. Each syconium of Ficus pertusa and of F. eximia colonized by one foundress had similar mean numbers of females, males, and seeds. The two species of wasps studied do not seem to adjust the sex ratio when there is superparasitism. Pollinating fig wasp behavior is better explained by those models not assuming that females do mathematical calculations according to other females' sex ratios, size, number of foundresses, genetic constitution, clutch size or environmental conditions inside the syconium. Our results are in agreement with the constant male number hypothesis, not with sex ratio games. Rev. Biol. Trop. 57 (3): 605621. Epub 2009 September 30.
\end{abstract}

Key words: sex ratio adjustment, local mate competition, fig pollinators, Pegoscapus, Costa Rica.

Nature is sometimes so complex that it should give pause to those who still think to solve the problem of parasite and host relations on paper by mathematical speculations. Salt 1936

A common theme in the discussions on the diversity of life is the division of reproduction into male and female functions (Werren 1987), and maternal manipulations of offspring sex ratio (King \& Skinner 1991 and references there in). Sex ratio evolution has been considered theoretically and empirically ever since Darwin (1871) posed the problem (Werren 1980); and wasps and bees are interesting on this regard because they are supposed to have a remarkable ability to control the sex ratio (adaptively shift) of their offspring during fertilization ("facultative" or "labile" control, Cook 1993, Frank 1983a, Werren 1980, 1987, Orzack \& Parker, 1990, Herre et al. 2008, and references therein) noted that "fig pollinating wasps... show the capacity to adaptatively shift sex ratios (in 
response to different number of foundresses)"; however, there are exceptions.

Many Hymenoptera are known to alter their sex ratio in response to a variety of environmental and physical local conditions (Clausen 1939, Charnov 1982, Strand 1987, Herre et al. 1997, Flanagan et al. 1998, King \& D'Souza 2004). Hartl (1971) stated that "one population genetic problem which assumes special importance in male haploids is the selection of an optimal sex ratio"; nevertheless, a female's best strategy is to produce only enough sons to fertilize all her daughters (Hamilton 1967, Hartl 1971). The sex ratio theory and models under LMC predict that colonizing females lay a higher proportion of males (sex ratio adjustment) as the number of females colonizing the same patch increases (Herre 1987, 1988, Cohen 1989, Herre et al. 1997, Kjellberg et al. 2005a). Furthermore, Werren (1980) noted that "those individuals making relatively small contribution to the mating population should bias investment towards male function"; while, according to West et al. (1997) "females that produce smaller clutches lay fewer males to produce the optimal sex ratio". Kjellberg et al. (2005b) noted "if many females enter a fig, they should produce about many sons as daughters as the situation will be closed to panmixis."

Biology of the fig wasps: The symbiotic pollinating fig wasps are local mate competition (LMC) organisms (Hamilton 1967, 1979, Herre 1985, Ramírez-Benavides 1987, Kjellberg et al. 1984, Herre et al. 1997, Pereira \& Prado 2005). The fig-wasp symbiosis is particularly intriguing because it is simultaneously a coevolved plant-pollinator association and plant-seed predator interaction (Bronstein 1994). The adult female wasps are short-lived and do not feed as adults (Pemberton 1921, Joseph 1958, Ramírez-Benavides 1970, Frank 1983b, Mathew 1984, Hill 1987, Moore et al. 2003) and they are not able to feed, especially on liquid, because they have an athrophied rigid maxilla and a labium without ligule (Ramirez-Benavides pers. obs.), they have multiple monotrophic ovarioles (Grandi 1920), usually mate once (Zavodna et al. 2005), are proovigenic; that is, all the eggs are mature and ready to be layed at female emergence (Nefdt 1989), oviposit one egg per female floret and usually lay all the eggs in a bout inside the same syconium ("fig fruit").

The syconia commonly close their ostiolar entrance shortly after some females penetrate, so the wasps enter and lay the eggs almost simultaneously (Ramírez-Benavides 1970, Frank 1983b, 1985, Herre 1985); they have symmetrical LMC; that is, synchronous oviposition and emergence of offspring (RamírezBenavides pers. obs.). The fig flowers remain suitable for oviposition for a relatively short time (Kathuria et al. 1999). The foundresses usually die inside the syconium after accomplishing total or partial oviposition, but there are reports of re-emergence and pollination of several figs (Moore et al. 2003).

Each larva develops independently inside a modified female fig floret which becomes transformed into a gall; there is no direct larval food competition or cannibalism; consequently, adult body sizes are not very variable (Ramírez-Benavides, pers. obs.) and the female larvae have a slower rate of development (Galil \& Eisikowitch 1971). The males are short-lived (Grandi 1920, Ramírez-Benavides 1970, Hill 1987) and mate with several females, which in turn usually mate just once and probably receive a limited number of spermatozoa or a spermatophore (Ramírez-Benavides, per. obs) or sperm capsules ( $c f$. Hartl 1971). Agaonid clutches are mostly female-biased. Pure male or pure female clutches are seldom found (Galil \& Eisikowitch 1971, West \& Herre 1998). Other LMC Hymenoptera may live relatively longer lives, are synovigenic, the adults have polytrophic ovaries and feed on sugary substances, as well as internal fluids (haemolymph) of their hosts, e.g., Nasonia vitripennis (Walker); (Werren 1980, Simbolotti et al. 1987, Murray 1990), and have asymmetrical LMC; that is, asynchronous laying and offspring emergence on a patch ( $c f$. Shuker et al. 2006). Furthermore, the mature eggs become available in discrete batches ( $c f$. Simbolotti et al. 1987). 
Sex allocation has been a productive and successful area of evolutionary biology (West et al. 2000). According to Herre et al. (1997), “elaborations of Hamilton's basic model have been tailored to the biology of fig pollinating wasps (Kjellberg 1983, Herre 1985, Frank 1985)". Until 1997 there were six known studies of sex ratios in fig-pollinating wasps (reviewed by Herre et al. 1997). According to Galil \& Eisikowitch (1971), "the fitness of a species as a whole, depends on fixed proportion between males and females...". Furthermore, when several females compete, individual clutch is reduced (Godfrey, 1994 in Kjellberg et al. 2005a). It has been assumed that inbred fig species, those where few foundresses enter each syconium for oviposition (e.g. one-foundress syconia) show the most female-biased sex ratios than outbred species (Herre 1985, Frank 1985 \& Herre et al. 1997). While according to West et al. (1996), as the number of foundresses increases, the sex ratio in the brood becomes less female biased. It has been also proposed for some species of parasitoid wasps that the sex ratio response to number of foundresses on a patch is in fact a response to the reduction of individual brood size (Godfray 1994, Kjellberg et al. 2005a). The majority of fig wasps species studied have shown brood sex ratios to be more female-biased than predicted (Hamilton 1979, Frank 1985, Herre 1985, Herre et al. 1997, Kinoshita et al. 2002, Moore et al. 2002). According to Hamilton's (1967) equal brood assumption, sex ratio increases in a patch from strong female-biased towards $1: 1$, and the game is not a zero-sum situation.

Frank (1985), Herre (1985, 1987) and West et al. (1996) noted "fig wasps may be able to assess or count the number of females currently laying eggs in a fig..." Chemical or genetic cues, left at the ostiolar entrance by female fig wasps, as well as genetic recognition have been suggested as possible mechanisms for some of these assumptions of the LMC models (Frank 1983a, 1983b, 1985). Several authors have stated that their data fit the model and that superparasitism results in a large proportion of male offspring (Werren 1980, Frank 1983a, Herre 1987, 1988, Orzack \& Parker
1990, Herre et al. 1997, West \& Herre 1998, Kathuria et al. 1999).

Kathuria et al. (1999) suggested that "previous LMC models may have given the right answer for the wrong reasons"; while Moore et al. (2002) noted that "pollinating fig wasps may fail to fit the predictions of classical sex ratio theory...", that "a foundress could approximate the predictions of LMC theory without knowledge of others ovipositing if they produce the same number of males regardless of the number of offspring produced and that those ovipositing in multi-foundress broods, suffer a reduction of clutch size". Other authors consider the assumptions of the LMC model unrealistic, doubt that females control sex ratios via arrhenotoky and mention a severe lack of empirical testing for the extensions of LMC theory (Frank 1985, Orzack \& Parker 1990, Orzack et al. 1991, Orzack \& Sober 1994, Flanagan et al. 1998, Shuker et al. 2004).

Multiple fig wasp foundress broods generally showed more females than the unadjusted model predicted (Hamilton 1979, Frank 1983b, cited by Herre et al. 1989, Kinoshita et al. 2002 and references therein), and the observed sex ratios are too low or more female-biased to be accounted by the theory (Hartl 1971, Herre et al. 1997, Pereira \& Prado 2006). Broods that contained exceptionally high proportions of males (0.5-1) have been attributed to spermdepleted or virgin females (West \& Herre 1998 and references therein, Pereira \& Prado 2006). However, pure or almost pure male clutches may be also produced when many foundresses $(5+)$ oviposit simultaneously in a one-foundress syconium (Ramírez-Benavides, pers. obs.).

Other authors think that LMC species are highly inbred, and those with a rigid precise sex ratio will be at a selective advantage over those that allocate males at random; furthermore, wasps can use arrhenotoky to produce such a precise sex ratio (Green 1980, Waage 1982, Green et al. 1982, Waage \& Lane 1984). Ramírez-Benavides (1987) observed that the pollinating fig wasps have precise sex ratios and lay male eggs first in the sequence. Moreover, Green et al. (1982) suggested that 
"the male eggs are produced at some particular place in the (laying) sequence"; while, Clausen (1939) argued that "the idea of sex ratio of any haploid species being a fixed figure was entirely untenable." However, Moore et al. (2005) demonstrated that females adjust sex ratio according to their clutch size, and suggested male eggs being laid mostly first, as a mechanism to explain sex ratio variation. Finally, according to Raja et al. (in press) the cues used by foundress to assess potential LMC, have not previously been determined; while Strand (1987) noted that "few cases provide evidence of sex ratios being influenced by physiological or genetic processes".

In this paper we report on a study that tested the hypothesis that two Costa Rican Pegoscapus fig wasps (1) are not able to assess the number of foundresses per syconium and (2) define brood sex ratio by laying a constant number of male eggs (constant male hypothesis), independently of clutch size and superparasitism.

\section{MATERIALS AND METHODS}

We used the fig wasps Pegoscapus silvestrii (Grandi 1919) pollinator of Ficus pertusa L.f. and Pegoscapus tonduzi (Grandi 1919) pollinator of F. eximia Schoot. (=F. citrifolia sensu Berg 1989). The fig species belong to subgenus Urostigma (section Americana). They usually have synchronous blooming, normally produce one-foundress broods (sensu Herre 1989) and have similar interfloral phases (C) of circa 45 days (time from pollination to eclosion of the new wasp generation). Both wasp species were originally described from the Central Valley of Costa Rica (Ramírez-Benavides, pers. obs., $c f$. Wiebes 1966). Note: we believe that the Ficus pertusa studied by West \& Herre (1988 and related papers) is misidentified ( $c f$. Humboldt et al. 1815 , page 47), and may be $F$. padifolia $H B K$, and that $F$. eximia corresponds to Ficus 2 studied by Hamilton (1979; RamírezBenavides, pers. obs).

Naturally colonized $F$. eximia and $F$. pertusa syconia from natural growing fig trees were collected one day before they reached the male phase (time of wasp eclosion) in Santo Domingo, Heredia, Costa Rica $\left(9^{\circ} 58^{\prime} 46.23\right.$ " N, $\left.84^{\circ} 4^{\prime} 52.14^{\prime \prime} \mathrm{W}\right)$. Each syconium was enclosed individually in a tightly capped glass jar. When the wasps emerged, they were killed with acetone and preserved in $70 \%$ ethanol. All foundresses and offspring were counted under a dissecting microscope. None of the syconia had kleptoparasitic or parasitic wasps, or cecidomyiid gall midges. Seeds from individual syconia of both fig species were also counted. Each sample size consisted of twenty five or more syconia; the data were not transformed, and all cases were included in the analysis.

We explain our terms, to avoid nomenclatural confusion common in the literature. We define a "brood" as the wasps emerging from a single syconium, regardless of the number of foundresses, equal to the "overall brood" of Kathuria et al. (1999). "Clutch" is the number of adult wasps produced by a foundress. "Sex ratio" means the percentage of males in relation to female in a clutch or brood, "Gall flowers" are those fig florets or pistillodes where the wasps are able to oviposit (cf. Ramírez-Benavides 2007). "Syconium" is the fig inflorescence, equivalent to the host or deme of Frank (1983b), and to the fruit of West \& Herre (1988). "One-foundress brood syconia" are those that are usually colonized by one or a few foundresses and allow full oviposition of at least one foundress. "Multi-foundress brood syconia" are those usually colonized by two or more foundresses and allow full oviposition (complete egg load) of at least two foundresses. "Superparasitism" refers to the presence of more than one foundress ovipositing in a syconium. "Symmetrical LMC" refers to synchronous oviposition and offspring emergence. "Fig wasps" refers only to the agaonid pollinators. "Optimal sex ratio" refers to the total oviposition (males + females) of a given foundress. "Pure or almost pure male brood syconia" are those that have very few females because their foundresses are too weak to oviposit the total egg load (Ramírez-Benavides, pers. obs) or those colonized by an unusual 
number of foundresses $(5+)$. Those syconia reach the male phase (D) but do not enlarge or become soft. They remain green on the tree for longer periods than those that develop normally without reaching the post-floral phase (E). For developmental syconial floral phases, see Galil \& Eisikowitch (1968).

The males of the two fig wasps studied have not been observed to disperse from their natal fig, and the foundresses are not known to re-emerge once that they penetrate a receptive syconium; thus, they die inside. For data analysis, we used ANOVA test.

\section{RESULTS}

P. silvestrii in tree number one: There were no differences in the mean number of males produced by foundress when one, two or three foundresses oviposited in a syconium (Table 1), or when one or two oviposited in a syconium that had almost pure males broods (Table 2). In another case in which syconia also had almost pure male clutches the male means were: $7.38 \pm 2.57$ for one $F(n=18), 9.85 \pm 2.35$ for two $F(n=7)$ and $6.17 \pm 3.06$ for three $F(n=$ 2). The means differed due to the drop of the mean of the three foundresses. However, there were no differences in the number of females when one, two and three foundresses oviposited in a syconium with almost pure male clutches (Table 3). Syconia $(n=34)$ oviposited by a sole foundress produced a mean of $9.23 \pm 2.48$ males, and the mean sex ratio was $7.65 \pm 1.78$ (Table 4). The mean number of females was $120.41 \pm 13.43$, and that of seeds $110.21 \pm 29.67$ )

TABLE 1

Mean number of males produced by foundress of Pegoscapus silvestrii in syconia colonized by one, two, three or four foundresses (tree number 1)

$\begin{array}{ccccccc}\text { Cases } & \text { Foundresses per sycocium } & 0^{\pi} / \text { Foundress } & \text { S.D. } & \text { C.V. } & \text { Dif. } \\ 58 & 1 & 8.39 & 2.67 & 0.31 & \mathrm{~ns} & \mathrm{~ns} \\ 19 & 2 & 8.15 & 3.36 & 0.41 & \mathrm{~ns} \\ 6 & 3 & 8.55 & 2.67 & 0.31 & & \\ 1 & 4 & 8.75 & & & \end{array}$

TABLE 2

Mean number of males produced by foundress in syconia of Pegoscapus silvestrii with almost pure male broods, colonized by one, two, three or four foundresses (tree number 1)

$\begin{array}{cccccc}\text { Cases } & \text { Foundress } & \text { O }^{\top} / \text { Foundress } & \text { S.D. } & \text { C.V. } & \text { Dif. } \\ 18 & 1 & 7.94 & 2.86 & 0.36 & \mathrm{~ns} \\ 5 & 2 & 9.30 & 2.64 & 0.28 & \mathrm{~ns} \\ 2 & 3 & 6.17 & 3.06 & 0.50 & \end{array}$

TABLE 3

Mean number of females produced by foundress of Pegoscapus silvestrii in syconia with almost pure male broods, colonized by one, two, three or four foundresses (tree number 1)

$\begin{array}{cccccc}\text { Cases } & \text { Foundress } & \text { 万'/ Foundress } & \text { S.D. } & \text { C.V. } & \text { Dif. } \\ 18 & 1 & 1.67 & 2.59 & 1.55 & \mathrm{~ns} \\ 7 & 2 & 0.21 & 0.27 & 1.25 & \mathrm{~ns} \\ 2 & 3 & 0.17 & 0.24 & 1.41 & \mathrm{~ns}\end{array}$


TABLE 4

Mean number of males, sex ratio, females and seeds produced in syconia colonized by one foundress of Pegoscapus silvestrii (tree number 1)

\begin{tabular}{|c|c|c|c|c|}
\hline Cases & Foundress & $\sigma^{\pi} /$ Foundress & S.D. & C.V. \\
\hline 34 & 1 & 9.23 & 2.48 & 0.26 \\
\hline Cases & Foundress & $q /$ Foundress & S.D. & C.V. \\
\hline 34 & 1 & 120.41 & 13.43 & 0.11 \\
\hline Cases & Foundress & Seeds & S.D. & C.V. \\
\hline 34 & 1 & 110.21 & 29.67 & 0.26 \\
\hline Cases & Foundress & Sex ratio & S.D. & C.V. \\
\hline 34 & 1 & 7.65 & 1.78 & 0.23 \\
\hline
\end{tabular}

(Table 4). Each male had the potential to fertilize 13 females.

P. silvestrii in tree number two: There were no differences in the mean number of males produced by foundress when one or two foundresses oviposited in a syconium (Table 5), nor in their sex ratios (Table 6). However syconia with one foundress produced a mean of $113.94 \pm 11.44$ females, while those with two foundresses produced a mean of $67.93 \pm 17.72$. Consequently, the number of females produced by foundress when two foundresses oviposited in a syconium dropped $60 \%$ while that of the males dropped $77 \%$ (Table 7).

TABLE 5

Mean number of males produced by one foundress of Pegoscapus silvestrii in syconia colonized by one or two foundresses (tree number 2)

$\begin{array}{cccccc}\text { Cases } & \text { Foundress } & 0^{\top} / \text { Foundress } & \text { S.D. } & \text { C.V. } & \text { Dif. } \\ 18 & 1 & 9.78 & 5.1 & 0.53 & \mathrm{~ns} \\ 5 & 2 & 7.50 & 3.90 & 0.52 & \mathrm{~ns}\end{array}$

TABLE 6

Mean sex ratio produced by foundress in syconia colonized by one or two foundresses of Pegoscapus silvestrii (tree number 2)

$\begin{array}{cccccc}\text { Cases } & \text { Foundress } & \text { Sex ratio } & \text { S.D. } & \text { C.V. } & \text { Dif. } \\ 18 & 1 & 8.60 & 4.40 & 0.51 & \text { ns } \\ 7 & 2 & 10.55 & 4.50 & 0.43 & \text { ns }\end{array}$


TABLE 7

Mean number of females produced in syconia with one or two foundresses of Pegoscapus silvestrii (tree $N^{\circ} 2$ )

\begin{tabular}{ccccc} 
Cases & Foundress & O / Foundress & S.D. & C.V. \\
\hline 18 & 1 & 113.94 & 11.44 & 0.10 \\
5 & 2 & 67.93 & 17.72 & 0.26
\end{tabular}

Pooled means of males of $P$. silvestrii obtained in tree number one (Table 1) and tree number two (Table 5): The mean number of males produced by foundress were: $8.72 \pm 3.44$ for one $\mathrm{F}(\mathrm{n}=76), 7.98 \pm 3.45$ for two $\mathrm{F}(\mathrm{n}=26)$ and $8.55 \pm 2.67$ for three $\mathrm{F}(\mathrm{n}=6)$. There were no differences between the means of one or two foundresses of both trees. The overall mean for any number of foundresses $(n=109)$ was $8.54 \pm 3.38$. Fig. 1 illustrates the means for both trees when there were one, two, three or four foundresses.

P. tonduzi in tree number one: There where no differences in the number of males produced by foundress, when one or two foundresses oviposited in a syconium (Table
$8)$. However syconia with unusual numbers of foundresses (5-17), had practically pure male broods and the number of males produced per foundress ranged from 6.47 through 18.01 (Table 9), while those of the females ranged from 0.00 to 2.18 , but the sample size did not allow statistical testing. A syconium had 190 males and two females.

P. tonduzi tree number two: Syconia $(\mathrm{n}=$ 23) colonized by one foundress had a mean of $125.44 \pm 26.15$, females + males $117.70 \pm 24.17$ females, $78.60 \pm 15.02$ seeds and a total of $204.04 \pm 31.21$ wasps plus seeds. The means for each case showed a low statistical variability. However, the mean number of males $7.74 \pm 5.79$ was more variable. The sex ratio was 6.57 .

TABLE 8

Mean number of males produced by foundress of Pegoscapus tonduzi in syconia colonized by one, two or three foundresses (tree number 1)

$\begin{array}{cccccc}\text { Cases } & \begin{array}{c}\text { Foundresses per } \\ \text { sycocium }\end{array} & \mathrm{O}^{\top} / \text { Foundress } & \text { S.D. } & \text { C.V. } & \text { Dif. } \\ 19 & 1 & 8.74 & 3.72 & 0.42 & n s \\ 11 & 2 & 10.63 & 3.11 & 0.29 & n s \\ 1 & 3 & 12 & & & \end{array}$

TABLE 9

Mean number of males produced by foundress of Pegoscapus tonduzi in syconia with 5 to 17 foundresses with pure male clutches (tree number 1)

$\begin{array}{cccc}\text { Cases } & \text { Foundresses per sycocium } & \sigma^{\top} / \text { Foundress } & \text { O / Foundress } \\ 2 & 5 & 18.01 & 0.10 \\ 1 & 8 & 6.75 & 0.00 \\ 2 & 10 & 8.35 & 0.00 \\ 1 & 11 & 12.09 & 2.18 \\ 1 & 14 & 8.43 & 0.41 \\ & 17 & 6.47 & 0.41\end{array}$




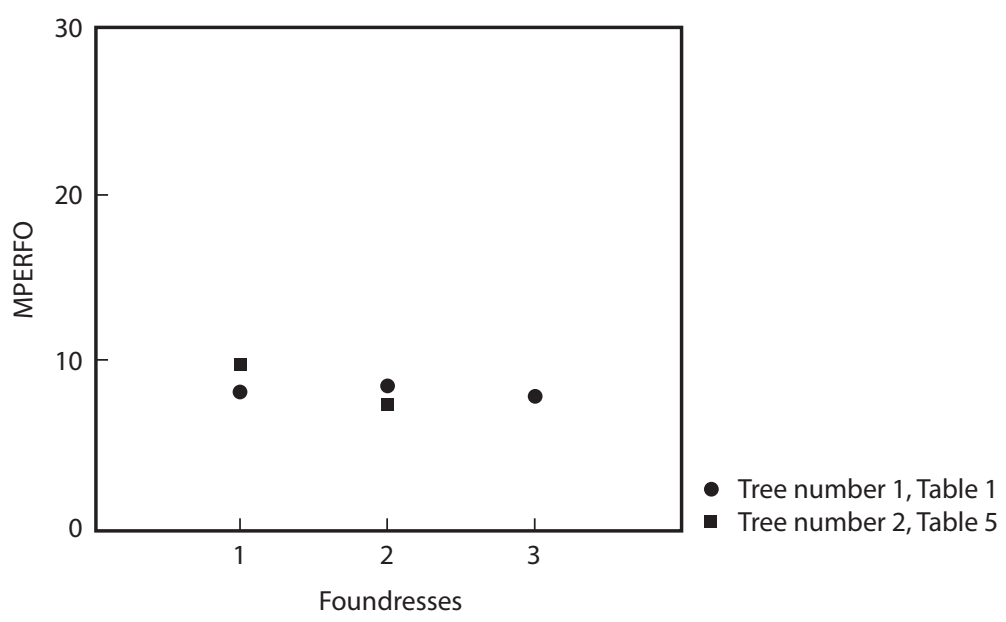

Fig. 1. Mean number of males produced by foundress of Pegoscapus silvestrii, when there one, two or three foundresses in syconia.

Pooled male means of $P$. silvestrii and P. tonduzi (Tables 4, 5 and 7): The mean number of males produced by foundresses was: $8.82 \pm 4.02$ for one $\mathrm{F}(\mathrm{n}=55), 9.39 \pm 3.43$ for two $\mathrm{F}(\mathrm{n}=23)$, and $8.11 \pm 4.01$ for $3 \mathrm{~F}(\mathrm{n}=3)$. The means did not differed, and the overall mean was 8.73 .

The pattern found, i.e., a greater number of foundresses did not affect the mean number of males produced by foundress, regardless of clutch size, and it was the same in both species $P$. silvestrii and $P$. tonduzi, as also found by Moore et al. (2002) for Liporrhopalum tentacularis, (= to Blastophaga (B.) tentacularis Grandi, $c f$. Wiebes 1996), a wasp that inhabits syconia of a gynodioecious fig species, of series Copiosae (cf. Wiebes 1978).

\section{DISCUSSION}

Males per foundress and sex allocation: The sex ratio (7.65) found for one foundress of $P$. silvestrii was similar to those reported for other fig wasps species (Grandi 1920, Condit 1947, Joseph 1958, Galil \& Eisikowitch 1971, Hamilton 1979, West et al. 1996, West \& Herre 1998, Pereira \& Prado 2006, Zavodna et al.
(2005) and not very different from that (8.7) reported by Werren (1980) for N. vitripennis (Pteromalidae). The sex ratio for $P$. tonduzi was 6.57, similar to the 6.9 reported in West et al. (1997, Table 11).

In fig wasps that colonize one-foundress brood syconia, as the two species studied, the most female biased sex ratio is achieved when only one foundress colonizes a syconium (West \& Herre 1998), and when her larvae are not subject to kleptoparasitism or other kinds of parasitism, (cf. Mathew 1984) as found in the present work. Pereira \& Prado (2005) found that "non-pollinating wasps (especially Idarnes sp.) had a direct effect in distorting the sex ratio of P. tonduzi broods", and cecidomyiid gall midges may have the same effect (RamírezBenavides pers. obs; Herre et al. 1997). Since only the female agaonids transport and disperse pollen, and perform pollination, the production of extra males in a fig brood represents a loss for the symbiotic wasp, as well as for its fig host; while too few males will also be detrimental because it will result in unmated females or even a complete loss of the brood (West \& Herre 1998). However, "extra sons may be favoured to reduce the probability that all males in a pach die" (West et al. 1997). 
Sex ratio in multifoundress syconia: In fig species with multi-foundress syconia, e.g., Ficus carica L. (pollinator Blastophaga psenes L.), there is no strong competition for the "gall flowers"; thus, the foundresses, especially the first ones to oviposit, do not adjust the sex ratios up to a certain limit $n=5-10$ (Kjellberg et al. 1984, Kathuria et al. 1999; Tayou 1991), cited by Moore et al. (2002), cf. Greeff \& Compton (1996) and Neft (1989) for Ceratosolen capensis, and Moore et al. (2002) for L. tentacularis. However, West \& Herre (1998) stated that in "the extreme case of fig wasp species in which single foundresses never occur, there would not be selection on a single foundress sex ratio and any amount of variance in that ratio would be tolerated". Moreover, Herre (1985, 1987, 1989) and Herre et al. (1997) noted that the more inbred species show the most female biased brood sex ratios for any particular number of foundresses (cf. Werren 1987 second prediction). Contrary to those authors, in fig wasp species that normally have a lower foundress number, (more inbred species) the sex ratio of each foundress becomes less female biased with increasing foundress density in agreement with Moore et al. (2002, 2005); cf. Stublefield \& Seger (1990), West et al. (1996) and West et al. (2005).

The number of female eggs laid by each foundress, and the sex ratio in species with oneor multi-foundress brood-syconia seems to depend indirectly on two environmental factors: 1) the presence of a pool of potentially "galling flowers" available for oviposition (host size) in agreement with Raja et al. (in press), and 2) the number of foundresses (density) simultaneously ovipositing in a syconium. Contrary to Moore et al. (2005) and Raja et al. (in press), the foundresses do not seem to use clutch size as a cue to asses potential LMC, or to assess the number of other foundresses ovipositing in a syconium, as assumed by Frank (1985).

Total males, females, and seeds per syconium: The results obtained for the mean number of males and females produced by foundress of $P$. silvestrii and P. tonduzi, suggest that each foundress oviposits an equal number of male eggs first in the sequence, in agreement with the constant male hypothesis, independently of superparasitism or clutch size (as assumed by Frank 1983b), ignoring the possibility of current or future presence of other foundresses, and that they withhold oviposition of female eggs (variable fecundity) when there is "superparasitism" (several foundresses); thus, clutch sizes differ in size, as in some of the assumptions of Werren (1980) and Frank (1983b, 1985) in agreement with Godfrey (1994) in Kjellberg et al. (2005a). As a result, the number of males in a brood increases proportionately with foundress density, as hipothesized by Moore et al. (2002). However, our results do not agree with Kjellberg et al. (2005a), Moore et al. (2005), who demonstrated that females adjust sex ratio according to clutch size by laying more male eggs when their clutch is small. The mean sex ratio per $P$. silvestrii when there was a single foundress was 7.65; and the pooled sex ratio for the clutches derived from one or two foundresses was 8.54: these ratios did not differ significantly. Each syconium of $F$. pertusa pollinated by a single foundress had a mean of $110.21 \pm 29.67$ seeds, $9.23 \pm 2.48$ males, $120.41 \pm 13.43$ females. While each syconium of $F$. eximia colonized by a single foundress had a mean of $78.60 \pm 15.02$ seeds, $7.74 \pm 4.02$ males, $117.70 \pm 24.17$ females, and the sex ratio was 6.57 .

Since the agaonid pollinators have monotrophic ovaries and are proovigenic they seem to have a limitation on the total number of eggs produced. Most agaonids studied produced around 150 or less eggs (RamírezBenavides, pers. obs.; West \& Herre 1998). Grandi (1920) reported 130-182 ovarioles for Blastophaga psenes. Furthermore, the agaonid species studied, seem to have a fixed strategy for sex allocation because: 1 - they do not eat as adults, 2- foundress number as well as resource size are quite constant per fig species, and 3the syconia on a fig tree usually are temporarily and spatially predictable.

Each syconium of $F$. pertusa observed had a limiting number of potential "galling 
flowers" (circa 130); thus, the foundresses were "forced" to "adjust" the number of eggs laid. Consequently the clutch size of each foundress decreased, as also noted by Moore et al. (2005), Raja et al. (in press) for L. tentacularis, and by Kathuria et al. (1999) for Eupristina belagaumensis in India. Our results show that the sex ratio produced by a foundress becomes more female-biased as they oviposit more eggs, in agreement with Herre (1987), and that superparasitized syconia have a greater proportion of sons in their broods, as found by Molbo \& Parker (1996) for $N$. vitripennis, and by Pereira \& Prado (2006) for P. tonduzi. Thus the sex ratio adjustments between foundresses were apparently not caused by the number of males produced as also noted by Raja et al. (in press), or by environmental predictability and mechanistic cues, as supported by West and Sheldon (2002) and West et al. (2005). Contrary to the facultative male adjustment hypothesis (FMA) and to Kjellberg et al. (2005a), P. silvestrii had precise sex ratios and did not bias the sex ratio by laying more male eggs when there were 1-3 foundresses; thus, they do not seem to play complicated mathematical sex ratio games. Contrary to Hamilton $(1967,1979)$, the game played by the wasps studied seem to be a zerosum strategy; consequently, Hamilton's (1967) equilibrium ratio (1:1), or equal brood size, does not occur.

Our results support and generalize those of Green et al. (1982) and those of West \& Herre (1998) about precise sex ratios. According to West \& Herre (1998) "precise sex allocation is theoretically advantageous when producing single sex broods". Nevertheless, Herre et al. (1997) quoting Herre (1985) and Frank (1985) noted that there is strong evidence for true facultative shifts in several of the (fig wasp) species because the number of males per foundress increases with foundress number. It is probable that the sex ratios of the agaonids studied are genetically fixed, as also assumed by Frank (1983a), and may depend on physiological properties or constrains as suggested by Raja et al. (in press); thus, they lay enough sons to inseminate his sisters ( $c f$. Hamilton
1967), and do not seem to depend on outside cues that induce facultative adjustments as supported by West et al. (2005). Furthermore, each agaonid species may have a limitation (strong constrain) on the total number of eggs to be laid due to specific size, as noted by Herre (1989). Additionally, each foundress carries a total number of eggs that do not exceed the number of flowers available for oviposition in a syconium (Ramírez-Benavides, pers. obs.)

In our case, there was an additive effect between the number of foundresses ovipositing in a syconium and the total number of males produced in a brood, as noted by Frank (1983a) for two Floridan Pegoscapus species, for P. tonduzi in Brazil (Pereira \& Prado 2006) and by Raja et al. (in press) for L. tentacularis. As a consequence, the more foundresses the less LMC; thus, the brood sex ratio rises with increasing foundress number, as also found by Herre (1985) for three Panamanian fig wasp species, among them, $P$. tonduzi. In agreement with Strand (1987), the deviations from the optimal sex ratios were not random as noted by Herre (1987). Furthermore, Strand (1987) noted that "with a variable strategy, non-random allocation might be favored to assure the presence of males in all broods".

When there were two foundresses of P. silvestrii, the number of daughters produced per foundress dropped $60 \%$. This result agrees with West \& Herre (1994), and Anstett et al. (1996), who noted that "the number of foundresses (foundress density) that enter a syconium to oviposit have a large effect on the average number of offspring (clutch size) produced per foundress" (Herre 1989, Bronstein 1994, Jousselin et al. 2001, Zavodna 2004 \& Moore et al. 2005); as well as, on brood sex ratio (cf. Moore et al. 2002). Our results also agree with those of Herre (1989) who found that as the number of foundresses rose, the average offspring per foundress fell, as also noted by Frank (1983b) and Kathuria et al. (1999). The pooled mean number of males produced by foundress of $P$. silvestrii in tree number one and tree number two did not differed significantly; additionally, the pooled mean number 
of males produced by foundresses of $P$. silvestrii and P. tonduzi did not differ significantly, and for $P$. silvestrii there was low variation in the number of males and females produced by a sole foundress.

Contrary to Kjellberg et al. (2005a), the agaonid species studied by us seem to oviposit a set of male eggs first in the laying sequence as suggested by Kinoshita et al. (2002), Moore et al. (2002) and Raja et al. (2005), independently of the clutch size of each foundress or knowledge of other foundresses ovipositing into a syconium, as one of possible mechanisms that would allow approximately optimal behavior in the oviposition strategy, as noted by Neft (1989) and Kathuria et al. (1999). This should strongly affect the brood sex-ratio and reproductive strategy, toward laying mainly male eggs when there are more than five foundresses in a syconium ( $c f$. Kathuria et al. 1999); as found in the present work for $P$. tonduzi when there were five to seventeen foundresses per syconium. Raja et al. (in press) noted for L. tentacularis that the females produce mainly male offspring at the start of the bouts. Some other parasitic LMC species are also known to lay male eggs first during an oviposition bout (Browne 1922, Green et al. 1982, Waage 1982, Waage \& Lane 1984). Varroa jacobsoni Oudemans, a parasite mite of the honeybee, is a LMC organism, has precise sex ratios, and a single male egg is laid first in the sequence (Ramírez-B 1987, Rehm \& Ritter 1988). Werren (1980, 1983, 1987) noted that data for Nasonia vitripennis suggest "that $100 \%$ sons were produced when a foundress laid relatively few eggs."

Considerable work has been carried out for testing sex ratio using pollinating fig wasps (Kathuria et al. 1999). Our results agree with the model of Werren (1980) who extended Hamilton's model (of the equal brood assumption) by adding the realistic assumption "that broods contributing to local mate competition differ in size", as found by Kathuria et al. (1999), and to Frank's (1983b) model, who assumed different clutch sizes among female fig foundresses (Moore et al. 2002, 2005, cf. Kjellberg et al. 2005, Raja et al. in press), and with those of Flanagan et al. (1998) who found for $N$. vitripennis that the sex ratio produced by individual females was negatively correlated with the number of offspring laid. They also agree with the conclusions of Waage (1982) who noted that in scelionid wasps, males and females are assigned non-randomly in a manner that ensures mixed broods in the proper proportion for a particular species. Our results showed how precisely adapted the wasps studied are, and that they "violate" previous assumptions of the LMC model as well as Fisher's (1930) implicit assumptions.

The theory of sex ratios for subdivided populations has been exceptionally rich with predictions (Frank 1983a, 1985), and theoretical attention (Frank 1985). In our case, we demostrated statistically that two neotropical Pegoscapus species in Costa Rica do not modify their sex ratio by laying more male eggs when more than one foundress enter and oviposit in a syconium; thus, they do not seem to "count and decide". Pollinating fig wasp behavior is better explained by those models not assuming equal foundress contributions to a brood, or that females have knowledge of other females' sex ratios, as noted by King \& D'Souza (2004) for Nasonia vitripennis, number of fertilized or virgin foundresses, genetic relationships, male mortality, previous parasitization or the environmental conditions inside the syconium.

By laying a constant number of male eggs first in the sequence, each fig wasp foundress provides an equal reproductive contribution to the mating population, and increases the number of mates for each son (Flanagan et al. 1998), and takes advantage of the mating opportunities afforded by other clutches, as noted by Moore et al. (2002). A male of $P$. silvestrii would produce a minimum of 13 sets of approximately 130 grandchildren each; while, a fertilized female would produce only one set of grandchildren (Ramírez-Benavides, pers. obs.); then, a new born male has better mating prospects than a new born female (cf. Hamilton 1967). Consequently, an oviposited male egg means a higher fitness return 
(Ramírez-Benavides, pers. obs.). In appendix 1 we summarize possible reasons why agaonid wasp male eggs are laid first.

Fig species with one-foundress brood syconia allow full oviposition by one foundress, as found out in the present work. We postulate that blastophagy, as well as local mate competition, evolved in fig species with microspermous and small one-foundress brood syconia; since they conducted to the stability and size of the feeding resource and to the evolution of predispersal mating and that the large multi-foundress syconia, like $F$. carica, with up to 1350 gall flowers (Condit 1920) and F. punctata Thunb. with 18000 potentially galling flowers ( $c f$. Kjellberg et. al. 2001) represent a derived state in the Ficus-wasp pollinators association.

\section{ACKNOWLEDGMENTS}

We thank Gilbert Fuentes and the Organization for Tropical Studies (OTS) Library for they assistance with the literature and text, and William Eberhard (University of Costa Rica) for comments on an earlier draft, and two anonymous reviewers. We dedicate this article to William D. Hamilton, the first author to write about extraordinary sex ratios (Hamilton 1967).

\section{RESUMEN}

Las avispas (Hymenoptera: Agaonidae) que polinizan las inflorescencias de los higos (Moraceae: Ficus) tienen arrenotoquia obligatoria y una estructura reproductiva que calza con la de los organismos que "compiten para aparearse localmente" ("organismos LMC"). Tradicionalmente se ha supuesto que estos organismos ajustan la proporción machos: hembras ("sex ratio"), ovipositando proporcionalmente más machos cuando más de una hembra colonizadora ocupa un hospedero (e.g. un higo). Se evaluó la hipótesis con dos especies de avispas polinizadoras: Pegoscapus silvestrii, hospedero Ficus pertusa y P. tonduzi, hospedero: Ficus eximia $(=F$. citrifolia) en el Valle Central, Costa Rica. Se contó el número total de avispas y semillas a partir de siconos individuales, colonizados naturalmente. Ambas especies tienen una proporción fija machos:hembras y probablemente ponen los huevos macho de primero, independientemente de la cantidad de huevos que ovipositan. La postura de huevos machos y hembras no es aleatoria. Hubo un efecto aditivo constante entre el número de colonizadoras y el número de machos producidos en un siconio, mientras que el número de hembras disminuyó. Higos de F. pertusa y de F. eximia colonizados por una avispa, produjeron promedios similares de hembras, machos y semillas. Las dos especies de avispas estudiadas y probablemente otros polinizadores (especialmente aquellas que se desarrollan en especies de higos que poseen inflorescencias que son generalmente polinizadas por una avispa), no parece que posean facultades adaptativas para ajustar la proporción sexual ovipositando más huevos machos cuando hay superparasitismo (varias colonizadoras). La oviposición de las avispas de los higos se explica mejor por los modelos LMC que no suponen que las hembras conocen número, tamaño y fertilidad de otras colonizadoras, o las condiciones ambientales dentro del higo donde ovipositan. Nuestros resultados demuestran estadísticamente que cada avispa colonizadora (de las dos especies estudiadas), oviposita el mismo número de huevos macho, independientemente del superparasitismo, reconocimiento genético o el número de huevos ovipositados (o "clutch size"), de acuerdo con la hipótesis del número constante de machos. Los resultados obtenidos muestran que la selección de la relación machos: hembras en las avispas estudiadas difiere de lo creído anteriormente.

Palabras clave: ajuste de la proporción sexual, competencia por apareamiento a nivel local, polinizadores de los higos, Pegoscapus, Costa Rica.

\section{REFERENCES}

Anstett, M.C., J.L. Bronstein \& M. Hossaert-McKey. 1996. Resource allocation: a conflict in the fig-fig wasp mutualism. Evol. Biol. 9: 417-428.

Berg, C. C. 1989. Classification and distribution of Ficus. Experientia 45: 605-616.

Bronstein, J.L. 1994. Seed predators as mutualists: ecology and evolution of the fig-pollinator interaction, $\mathrm{p}$. 1-44. In E. Bernays (ed.). Insect-plant interactions. CRC Press, Boca Raton, Florida, USA.

Browne, F.B. 1922. On the life history of Melittobia acasta, Walker: a chalcidoid parasite of bees and wasps. Parasitology 14: 341-371.

Charnov, E.L. 1982. The theory of sex allocation. Princeton University Press. Princeton, New Jersey.

Clausen, C.D. 1939. The effect of host size upon the sex ratio of hymenopterous parasites and its relation of rearing and colonizations. J. New York Entomol. Soc. 47: 1-9.

Cohen, K. 1989. Sex ratio adjustment in pollinator wasps of three Australian fig species. B. Sc. Thesis, University of New South Wales, Australia. 
Condit, I.J. 1920. Caprifigs and caprification. Univ. Calif. Exp. Sta. Bull. 319: 341-75.

Condit, I.J. 1947. The Fig. Chronica Botanica Co. Waltham, Massachusetts, U.S.A.

Cook, J. 1993. Sex determination in the Hymenoptera: a review of models and evidence. Heredity 71: 421-435.

Darwin, C. 1871. The descent of man and selection in relation to sex. D. Appleton, New York.

Fisher, R.A. 1930. The genetical theory of natural selection. Clarendon Press, Oxford.

Flanagan, K.E., S.A. West \& H.C.J. Godfray. 1998. Local mate competition, variable fecundity and information use in a parasitoid. Anim. Behav. 56: 191-198.

Frank, S.A. 1983a. A hierarchical view of sex-ratio patterns. Flor. Entomol. 66: 42-75.

Frank, S.A. 1983b. Theoretical and empirical studies of sex ratios, mainly in fig wasps. M. Sc. Thesis, The University of Florida, Gainesville, Florida, USA.

Frank, S.A. 1985. Hierarchical selection theory and sex ratios. II. On applying the theory, and a test with fig wasps. Evolution 39: 949-964.

Galil, J. \& D. Eisikowitch. 1968. Flowering cycles and fruit types of Ficus sycomorus in Israel. New Phytol. 67: 745-758.

Galil, J. \& D. Eisikowitch. 1971. Studies on mutualistic symbiosis between syconia and sycophilous wasps in monoecious figs. New Phytol. 70: 773-787.

Godfray, H.C.J. 1994. Parasitoids: behavioral and evolutionary ecology (Monographs in behavior and ecology). Princeton University Press, Princeton, New Jersey.

Grandi, G. 1919. Contributo alla conoscenza degli Agaonini (Hymenoptera, Chalcididae) dell'America. Agaonini di Costa Rica. Boll. Lab. Zool. Portici 13: 15-56.

Grandi, G. 1920. Studio morfologico e biologico della Blastophaga psenes (L.). Boll. Lab. Zool. Portici 14: 63-204.

Greeff, J.M. \& S.G. Compton. 1996. Sequential oviposition and optimal sex ratios in pollinating fig wasps. Ecol. Entomol. 21: 300-302.

Green, R.F. 1980. Optimization of the sex ratio when family size and sex ratio can vary. Dept. Stat. Tech. Rep. No. 66, University of California, Riverside, California, USA.
Green, R.F., G. Gordh \& B.A. Hawkins. 1982. Precise sex ratios in highly inbreed parasitic wasps. Am. Nat. 120: 653-665.

Hamilton, W.D. 1967. Extraordinary sex ratios. A sexratio theory for sex linkage and inbreeding has new implications in cytogenetics and entomology. Science 156: 477-478.

Hamilton, W.D. 1979. Wingless and fighting males in fig wasps and other insects, p. 107-200. In M.S. Blum \& N.A. Blum (eds.). Sexual selection and reproductive competition in insects. Academic Press, New York.

Hartl, D.L. 1971. Some aspects of natural selection in arrhenotokous populations. Am. Zool. 11: 30-325.

Herre, E.A. 1985. Sex ratio adjustment in fig wasps. Science 228: 896-898.

Herre, E.A. 1987. Optimality, plasticity and selective regime in fig wasp sex ratios. Nature 329: 627-629.

Herre, E.A. 1988. Sex ratio adjustment in thirteen species of Panamanian fig wasps. Ph.D. Thesis, University of Iowa, Iowa, USA.

Herre, E.A. 1989. Coevolution of reproductive characteristics in 12 species of New World figs and their pollinator wasps. Experientia 45: 637-647.

Herre, E.A., S.A. West, J.M. Cook, S.G. Compton \& F. Kjellberg. 1997. Fig wasps mating systems: pollinators and parasites, sex-ratio adjustment and male polymorphism, population structure and its consequences, p. 226-239. In J.C. Choe \& B.J. Crespi (eds.). The evolution of mating systems: Social competition and cooperation in insects and arachnids.Princeton University Press, Princeton, New Jersey, USA.

Herre, E.A, K.C. Jandér \& C.A. Machado. 2008. Evolutionary ecology of figs and their associates: recent progress and outstanding puzzles. Annu. Rev. Ecol. Evol. Systemat. 39: 439-458.

Hill, D.S. 1987. Figs (Ficus spp.) and fig wasps (Chalcidoidea). J. Nat. Hist. 1: 413-434.

Humboldt, A., A.J.A. Bonpland and C.S. Kunth. 1815 (1963). Nova Genera et Species Plantarum. Vol. II. Wheldon Wesley and Hafner, New York.

Joseph, K.J. 1958. Recherches sur les chalcidiens, Blastophaga psenes (L.) et Philotrypesis caricae (L.) du figuier (Ficus carica L.). Ann. Sci. Nat. Zool. 20:197-260.

Jousselin, J., M. Hossaert-McKey, D. Verned \& J. Kjellberg. 2001. Egg deposition patterns of fig-pollinating 
wasps: implications for the studies of the stability of the mutualism. Ecol. Entomol. 26: 62-68.

Kathuria, P., J.M. Greef, S.G. Compton \& K.N. Ganeshaiah. 1999. What fig wasp sex ratios may or may not tell us about sex allocation strategies. Oikos 87: 520-530.

King, B.H. \& S.W. Skinner. 1991. Proximal mechanism of sex ratio and clutch size response by the wasp Nasonia vitripennis to parasitized hosts. Anim. Behav. 42: 23-32.

King, B.H. \& J.A. D’Souza. 2004. Effects of constrained females on offspring sex ratios of Nasonia vitripennis in relation to local mate competition theory. Can. J. Zool. 82: 1969-1974.

Kinoshita, M., E. Kasuya \& T. Yahara. 2002. Effect of time-dependent competition for oviposition sites on clutch sizes and offspring sex ratios in a fig wasp. Oikos 96: 31-35.

Kjellberg, F. 1983. La stratégie reproductive du figuier ( $F$. carica) et de son pollinisateur (Blastophaga psenes L.) un example de coévolution. Ph.D. Thesis, Institut National Agronomique, Paris-Grignon, France.

Kjellberg, F., D. Dangin, M. Valdeyron \& G. Ibrahim. 1984. Sex ratio in the progeny of related females breeding under local mate competition conditions. Mini Symposium Figs and Fig Insects. Centre Louis Emberger, Paris, France.

Kjellberg, F., E. Jousselin, M. Hossaert-McKey \& J-Y. Rasplus. 2001. Biology, ecology, and evolution of fig-pollinating wasps (Chalcidoidea, Agaonidae), p. 539-572. In Raman, A., W. Schaefer \& T.M. Withers (eds.). Biology, ecology and evolution of gall-inducing arthropods. Science Publishers, Inc. Enfield, New Hamshire, USA.

Kjellberg, F., J.L. Bronstein, G. van Ginkel, J.M. Greef, J.C., Moore, N. Bossu-Dupriez, M. Chevolot \& G. Michaloud. 2005a. Clutch size: a major sex ratio determinant in fig pollinating wasps?. C. R. Biologies 28: 471-476.

Kjellberg, F., E. Jousselin, M. Hossaert-McKey \& J-Y. Rasplus. 2005b. Biology, ecology, and evolution of fig-pollinating wasps (Chalcidoidea, Agaonidae), p. 539-572. In Raman, A., W. Schaefer \& T.M. Withers (eds.). Biology, ecology and evolution of gall-inducing arthropods. Science Publishers, Inc. Enfield, New Hamshire, USA.

Mathew, J. 1984. Morphology, biology and behavior of Ceratosolen fusciceps Mayr and its relationship with other Fig wasps breeding in the receptacles of Ficus racemosa L. Ph.D. Thesis, University of Calicut, India.

Molbo, D. \& E.D.Parker, Jr. 1996. Mating structure and sex ratio variation in a natural population of Nasonia vitripennis. Proc. Roy. Soc. London B 263: 1703-1709.

Moore, J.C., S.G. Compton, M.D. Hatcher \& A.M. Dunn. 2002. Quantitative test of sex ratio models in a pollinating fig wasp. Anim. Behav. 64: 23-32.

Moore, J.C., A.M. Dunn, S.G. Compton \& M.D. Hatcher. 2003. Foundress re-emergence and fig permeability in tree wasp mutualisms. J. Evol. Biol. 16: 11861195 .

Moore, J.C., M. Zadovna, S.G. Compton \& P.M. Gilmartin. 2005. Sex ratio strategies and the evolution of cue use. Proc. Roy. Soc. London B 222: 1287-1294.

Murray, M.G. 1990. Comparative morphology and mate competition of flightless male fig wasps. Anim. Behav. 39: 434-433.

Nefdt, R.J.C. 1989. Interactions between fig wasps and their host figs. M.Sc. Thesis (Zoology and Entomology). Rhodes University, Grahamstown, South Africa.

Nefdt, R.J.C. \& S.G. Compton. 1996. Regulation of seed and pollinator production in the fig-fig wasp mutualism. J. Anim. Ecol. 65: 170-182.

Orzack, S.H. \& E.D. Parker. 1990. The comparative biology as second sex ratios evolution with a natural population of a parasitic wasp, Nasonia vitripennis. Genetics 124: 385-396.

Orzack, S.H., E.D. Parker \& J. Gladstone. 1991. The comparative biology of genetic variation for conditional sex ratio behaviour in a parasitic wasp, Nasonia vitripennis. Genetics 127: 583-599.

Orzack, S.T. \& E. Sober. 1994. Optimality models and the test of adaptation. Am. Nat. 143: 361-380.

Pemberton, C.E. 1921. The fig wasps in its relation to the development of fertile seeds in the Moreton Bay fig. Hawaii. Plant. Rec. 24: 297-319.

Pereira, R.A.S. \& A.P. Prado. 2005. Non-pollinating wasps distort the sex ratio of pollinating fig wasps. Oikos 110: 613-619.

Pereira, R.A.S. \& A.P. Prado. 2006. Effect of local mate competition on fig wasp sex ratios. Braz. J. Biol. 66: 603-610. 
Raja, S., N. Suleman, S.G. Compton \& J.C. Moore. 2008. The mechanisms of sex ratio adjusment in a pollinating fig wasp. Proc. Roy. Soc. London B doi:10.1098/ rspb.2008.0136.

Ramírez-Benavides, W. 1970. Taxonomic and biological studies of neotropical fig wasps (Hymenoptera: Agaonidae). Univ. Kansas Sci. Bull. 46: 1-44.

Ramírez-Benavides, W. 1987. Biological analogies between some fig-wasps (Hymenoptera: Agaonidae and Torymidae: Sycophaginae) and Varroa jacobsoni (Acari: Varroidae). Rev. Biol. Trop. 35: 209-214.

Ramírez-Benavides, W. 2007. Pollination analogies between Orchidaceae, Ficus (Moraceae) and Asclepiadaceae. Lankesteriana: 450-457.

Rehm, S. \& W. Ritter. 1998. The succession and length of development of male and female offspring of Varroa jacobsoni in the worker brood, p. 3. In R. Cavalloro (ed.). Present status of varroatosis in Europe and progress in the Varroa mite control, Udine, Italy.

Salt, G. 1936. Experimental studies in insect parasitism of populations of Trichogramma evanescens. J. Exp. Biol. 13: 363-375.

Shuker, D.M., S.E. Reece, J.A.L. Taylor \& S.A West. 2004 Wasp sex ratios when females in a patch are related. Anim. Behav. 68: 331-336.

Shuker, D.M., I. Pen \& S.A West. 2006. Sex ratios under asymmetrical local mate competition in the parasitoid wasp Nasonia vitripennis. Behav. Ecol. 17: 345-352.

Simbolotti G., F.A. Putters \& J. van den Assem. 1987. Rates of attack and control of the offspring sex ratio in the parasitic wasp Lariophagus dintinguendus in an environment where host quality varies. Behavior 100: $1-32$.

Strand, M.R. 1987. Adaptive patterns of progeny and sex allocation by parasitic Hymenoptera, p. 393-312. In V.K. Gupta (ed.). Advances in parasitic hymenoptera Research. Leiden, New York.

Stubblefield, J.W. \& J. Seger. 1990. Local mate competition with variable fecundity: dependence of offspring sex ratios on information utilization and mode of male production. Behav. Ecol. 1: 68-80.

Tayou, A. 1991. Etude du mutualisme Ficus-polinisateur: sex ratio et transport du pollen. Ph.D. Thesis. Université Monpellier II. Paris, France.

Waage, J.K. 1982. Sib-mating and sex ratio strategies in scelionid wasps. Ecol. Entomol. 7: 103-12.
Waage, J.K. \& J.A Lane. 1984. The reproductive strategy of a parasitic wasp. II. Sex allocation and local mate competition in Trichogramma evanescens. J. Anim. Ecol. 53: 417-426.

Werren, J.H. 1980. Sex ratio adaptations to local mate competion in a parasitic wasp. Science 208: 1157-1159.

Werren, J.H. 1983. Sex ratio evolution under local mate competition in a parasitic wasp. Evolution 37: 116-124.

Werren, J.H. 1987. Labile sex ratios in waps and bees. BioScience 37: 498-506.

West, S.A. \& E.A. Herre. 1994. The ecology of the New World fig-parasitizing wasps Idarnes and implications for the evolution of the fig-pollinator mutualism. Proc. Roy. Soc. London B 258: 67-72.

West, S.A. \& E.A. Herre. 1998. Stabilizing selection and variance in fig wasp sex ratios. Evolution 52: 475 485 .

West, S.A., E.A. Herre \& B.C. Sheldon. 1996. The benefits of allocation of sex allocation. Science 290: 288-290.

West, S.A., E.A. Herre, S.G. Compton, H.C.J. Godfray \& J.M. Cook. 1997. A comparative study of virginity in fig wasps. Anim. Behav. 54: 437-450.

West, S.A., E.A. Herre, S.G. \& B.C. Sheldon. 2000. The benefits of allocating sex. Science 290: 288-290.

West, S.A. \& B.C. Sheldon. 2002. Constrains in the evolution of sex ratio adjustment. Science 2095: 1211-1228.

West, S.A., D.M. Shucker \& B.C. Sheldon. 2005. Sex ratio adjustment when relatives interact: a test of constraints on adaptation. Evolution 56: 1211-1288.

Wiebes, J.T. 1966. Provisional host catalogue of fig wasps (Hymenoptera, Chalicidoidea). Zool. Verh. Leiden 83:1-44.

Wiebes, J.T. 1978. The genus Kradibia Saunders and an addition to Ceratosolen Mayr (Hymenoptera Chalcidoidea, Agaonidae). Zool. Meded. Leiden 53:165-184.

Zavodna, M. S. 2004. On the biology of pollinating fig wasps and the maintenance of their mutualism with fig plants. Ph.D. Thesis, Utrecht University, The Netherlands.

Zavodna, M., S.G. Compton, S. Raja, P. Gilmartin \& J. Damme. 2005. Do fig wasps produce mixed paternity clutches? J. Insect Behav. 18: 351-362. 


\section{APPENDIX 1 \\ POSSIBLE REASONS WHY MALE EGGS OF AGAONID \\ WASPS ARE LAID FIRST IN THE SEQUENCE}

1. Females are physiologically constrained to oviposit all male eggs before female eggs (Ramírez-Benavides, pers. obs.).

2. The females probably receive a limited number of spermatozoa (RamírezBenavides, pers. obs.), enough to fertilize a certain number of eggs.

3. Since there is male homomorphism, all males have the same mating potential (Hart 1971).

4. Males develop more rapidly than females (Werren 1980, Mathew 1984 and Galil \& Eisikowitch 1970).

5. A male has more possibilities to contribute to future generations (Ramírez-Benavides, pers. obs.).

6. It is cheaper to produce a male egg because it does not require fertilization (RamírezBenavides, pers. obs.) and the total effort to produce a male is less than produce a female.

7. The unfertilized egg and the male larvae are more likely to survive (Joseph 1958, Hamilton 1967, Hart 1971).

8. The females probably oviposit the male eggs first in the sequence in the most accessible potentially galling flowers; that is, those in the most interior ovary layer inside the syconium, which probably also have the shorter styles and more accessible ovaries ( $c f$. Neft \& Compton 1995, Murray 1990).

9. Gall forming stimulation may start sooner in fig flowers containing a male egg (Ramírez-Benavides, pers. obs.).
10. There is a greater survival of male larvae under conditions of superparasitism ( $c f$. Hamilton 1967).

11. The male larvae are probably less subject to kleptoparasitism (Ramírez-Benavides, pers. obs. $c f$. Pereira \& Prado 2005).

12. The costs of male mortality are potentially high (Moore et al. 2002).

13. Since male births are less common than females, a newborn male has better mating prospects than a newborn female (Hamilton 1967).

14. Since mail births are less common than females, a new born male has better mating prospects than a new female (Hamilton 1967).

15. They reach adulthood with mature spermatozoa (Ramírez-Benavides, pers obs.)

16. They emerge from the galls before the females, during a short time, and usually do not fight among themselves and can mate many times ( $c f$. Hamilton 1967).

17. They become adults with mature spermatozoa (Ramírez-Benavides, pers. obs.)

18. They do not feed as adults (RamírezBenavides, pers. obs.).

19. They have limited locomotion (Murray 1990), and are usually unable to disperse.

20. They have a shorter adult life span (Joseph 1958, Hill 1967, Mathew 1984).

21. They reach adulthood and sexual maturation before the females migrate. 
22. They are polygamous (Joseph 1958, Ramírez-Benavides 1974, Werren 1980).

23. They mate inside the syconium when the females are inactive.

24. They have a higher probability of survival and reproduction (Galil \& Eisikowitch 1971).
25. Laying the male eggs first in the sequence avoids virginity of females in the brood.

26. By laying the male eggs first in the sequence, second foundresses take advantage of the mating opportunities afforded by other clutches (Moore et al. 2002).

Editor José A. Vargas Z. Associate Editor Daisy Arroyo M. 